\title{
Overlapping molecular pathways between cannabinoid receptors type 1 and 2 and estrogens/androgens on the periphery and their involvement in the pathogenesis of common diseases (Review)
}

\author{
LUKA DOBOVIŠEK ${ }^{*}$, MARKO HOJNIK ${ }^{*}$ and POLONCA FERK \\ Department of Pharmacology and Experimental Toxicology, Faculty of Medicine, \\ University of Maribor, SI-2000 Maribor, Slovenia
}

Received June 26, 2016; Accepted October 12, 2016

DOI: 10.3892/ijmm.2016.2779

\begin{abstract}
The physiological and pathophysiological roles of sex hormones have been well documented and the modulation of their effects is applicable in many current treatments. On the other hand, the physiological role of endocannabinoids is not yet clearly understood and the endocannabinoid system

Correspondence to: Professor Polonca Ferk, Department of Pharmacology and Experimental Toxicology, Faculty of Medicine, University of Maribor, Taborska ulica 8, SI-2000 Maribor, Slovenia E-mail: polonca.ferk@guest.arnes.si

*Contributed equally
\end{abstract}

Abbreviations: AC, adenylate cyclase; 2-AG, 2-arachidonoyl glycerol; Akt, serine-threonine specific protein kinase; cAMP, cyclic adenosine monophosphate; AP-1, activator protein-1; AR, androgen receptor; ATF-1, activating transcription factor-1; ATF-2, activating transcription factor 2; Bcl-2, B-cell lymphoma 2 protein; $\mathrm{CB} 1$, cannabinoid type 1 ; CB2, cannabinoid type 2; CB3, cannabinoid type 3; c-Jun, protein encoded by the $J U N$ gene; COX-2, cyclo-oxygenase-2; CRE, cAMP response elements; CREB, cAMP response element binding protein; DHT, dihydrotestosterone; DNA, deoxyribonucleic acid; EGF, epidermal growth factor; ER, estrogen receptor; EREs, estrogen response elements; ERK1/2, extracellular-signal-regulated kinases 1/2; FAAH, fatty acid amide hydrolase; FSH, follicle-stimulating hormone; GnRH, gonadotropin-releasing hormone; GPER, G protein coupled estrogen receptor; GPR18, G protein coupled receptor 18; GPR19, G protein coupled receptor 19; GPR55, G protein coupled receptor 55; IGF, insulin-like growth factor; LH, luteinizing hormone; MAGL, monoacylglycerol lipase; MAPK, mitogen-activated protein kinase; MEK, mitogen-activated protein kinase kinase; NAPE-PLD, N-acyl phosphatidylethanolamine phospholipase D; p21, cyclin-dependent kinase inhibitor 1; PI3K, phosphatidylinositol-4,5-bisphosphate 3kinase; PKA, protein kinase A; PKC, protein kinase C; PLC, phospholipase $\mathrm{C}$; Raf, proto-oncogene serine/threonine-protein kinase; Ras, rat sarcoma protein; SHBG, sex hormone-binding globulin; Src, proto-oncogene tyrosine-protein kinase; THC, tetrahydrocannabinol; VEGF, vascular endothelial growth factor

Key words: cannabinoids, estrogens, androgens, receptors, cancer, molecular signaling pathways, atherosclerosis, osteoporosis is considered a relatively new therapeutic target. The physiological association between sex hormones and cannabinoids has been investigated in several studies; however, its involvement in the pathophysiology of common human diseases has been studied separately. Herein, we present the first systematic review of molecular pathways that are influenced by both the cannabinoids and sex hormones, including adenylate cyclase and protein kinase A, epidermal growth factor receptor, cyclic adenosine monophosphate response element-binding protein, vascular endothelial growth factor, proto-oncogene serine/threonine-protein kinase, mitogen-activated protein kinase, phosphatidylinositol-4,5-bisphosphate 3-kinase, C-Jun N-terminal kinase and extracellular-signal-regulated kinases $1 / 2$. Most of these influence cell proliferative activity. Better insight into this association may prove to be beneficial for the development of novel pharmacological treatment strategies for many common diseases, including breast cancer, endometrial cancer, prostate cancer, osteoporosis and atherosclerosis. The associations between cannabinoids, estrogens and androgens under these conditions are also presented and the molecular interactions are highlighted.

\section{Contents}

1. Introduction

2. Cannabinoids

3. Estrogens

4. Cannabinoids and estrogens

5. Overlapping molecular pathways of cannabinoids and estrogens

6. Cannabinoids and estrogens in common diseases

7. Androgens

8. Cannabinoids and androgens

9. Overlapping molecular pathways of cannabinoids and androgens

10. Cannabinoids and androgens in common diseases

11. Conclusions

\section{Introduction}

The physiological and pathophysiological roles of the cannabinoid and sex hormone systems have been studied separately. 
In the present review, we suggest some common molecular pathways and possible interactions between cannabinoids and sex hormones in physiological and selected pathophysiological conditions. We hypothesized that the endocannabinoid system may have a body-wide protective role against the harmful effects of sex hormones.

\section{Cannabinoids}

Cannabinoid receptors are membrane receptors of the $\mathrm{G}$ protein-coupled receptor (GPR) superfamily. There are two subtypes of cannabinoid receptors, termed cannabinoid type 1 (CB1) and CB2 receptors. CB1 receptors are mostly present in the central nervous system, but are also expressed in peripheral tissues, such as endothelial cells, adipocytes and peripheral nerves. They are linked via Gi to the inhibition of adenylyl cyclase and voltage-operated calcium channels, influencing many secondary messengers (1). CB2 receptors are linked via Gi to adenylyl cyclase and mitogen-activated protein kinase (MAPK), but not to voltage-operated calcium channels. They are expressed in the immune system, gastrointestinal tract, peripheral nervous system and microglia of the brain (1). Recent findings suggest that cannabinoids can also activate other receptors, including vanilloid receptor 1 , GPR18, GPR19, GPR55 receptor, the latter being suggested as the CB3 receptor (2-5). There are many exogenous [i.e., tetrahydrocannabinol (THC), cannabidiol and cannabinol] and endogenous [anandamide, 2-arachidonoyl glycerol (2-AG), virhodamine, 2-arachidonoyl glycerol ether (noladin) and $\mathrm{N}$-arachidonoyl dopamine] substances that effect cannabinoid receptors (1).

\section{Estrogens}

Estrogens bind to estrogen receptors (ERs) $\alpha$ and $\beta$. ER complexes bind with high affinity and specificity to estrogen response elements (EREs) to regulate the transcription of target genes involved in the regulation of many complex physiological processes. ERs can sometimes regulate the expression of genes that lack EREs by modulating the transcriptional activity of other transcription factors (6). Some non-genomic effects of estrogens are known and are caused by the direct activation of ERs in the plasma membrane $(7,8)$.

A third estrogen receptor, $G$ protein coupled estrogen receptor (GPER, which is also known as GPR30), has also been discovered, although its functional role is still unclear (9). Modulation of the estrogen receptors is currently being considered for the prevention and treatment of a wide variety of pathological conditions, including osteoporosis, metabolic and cardiovascular diseases, inflammation, neurodegenerive disorders and cancer (10). Three estrogens are present in significant quantities in the plasma of human females: $17 \beta$-estradiol, estrone and estriol. The estrogenic potency of $17 \beta$-estradiol is kown to be 12 -fold greater than that of estrone and 80 -fold greater than that of estriol, making the total estrogenic efficiency of $17 \beta$-estradiol much greater than that of the other two combined. $17 \beta$-estradiol is the principal estrogen secreted by the ovaries; small amounts of estrone are also secreted, but most of the circulating estrone is formed in peripheral tissues from androgens (11).

\section{Cannabinoids and estrogens}

On the level of the hypothalamic-pituitary-gonadal axis, interactions between cannabinoids and estrogens have been well documented. Studies have indicated that the acute administration of THC, a non-selective $\mathrm{CB} 1$ and $\mathrm{CB} 2$ receptor agonist, decreases serum luteinizing hormone (LH) and gonadotropinreleasing hormone $(\mathrm{GnRH})$ secretion in ovariectomized female and intact male rats (12-14). Lower concentrations of GnRH [and consequently a decrease in LH and folliclestimulating hormone (FSH) concentrations] result in lower circulating estrogen levels. Anandamide, the main endogenous cannabinoid, produces similar results in both, female and male rats (15). Cannabinoids appear to modulate the release of $\mathrm{GnRH}$ through their effect on hypothalamic GnRH-releasing neurons with a high density of $\mathrm{CB} 1$ receptors and a relatively low density of CB2 receptors (16).

Fatty acid amide hydrolase (FAAH) is responsible for anandamide degradation (17). Estrogens decrease FAAH activity in the mouse uterus (18) and this leads to higher cannabinoid concentrations. In association with these findings, a previous study found that there was a positive correlation between peak plasma anandamide with peak plasma $17 \beta$-estradiol and gonadotrophin levels at ovulation (19). A possible underlying mechanism responsible for this phenomenon is that increased levels of estrogens at ovulation inhibit FAAH activity and consequently increase endocannabinoid plasma levels. Gorzalka and Dang published a detailed review describing the behavioral and reproductive aspects of cannabinoid and sex hormone interactions (20).

In addition, studies have demonstrated that $17 \beta$-estradiol increases the expression of $\mathrm{CB} 2$ receptors in osteoclasts in vitro, as well as the expression of $\mathrm{CB} 1$ receptors in human colon cancer $(21,22)$. In the brain, $17 \beta$-estradiol regulates CB1 expression in a region-dependent manner, providing a possible explanation for gender-related differences in sensitivity for the central effects of cannabinoids (23). Recently, selective estrogen receptor modulators (raloxifene, bazedoxifene and lasofoxifene) were discovered to act as inverse CB2 agonists (24). Furthermore, tamoxifen has been demonstrated to act as an inverse CB1 and CB2 agonist in breast cancer cells (25). This finding indicates that estrogens may also have a direct influence on $\mathrm{CB} 1$ and $\mathrm{CB} 2$ receptors.

\section{Overlapping molecular pathways of cannabinoids and estrogens}

Adenylate cyclase $(A C)$ and protein kinase A (PKA). Cannabinoid receptor agonists signal through the inhibition of the AC and PKA pathways (26). This is also one of the main signaling pathways of estrogens (27-29), activated by the binding of $17 \beta$-estradiol to ERs (Fig. 1) and partly by non-genomic mechanisms of estrogen action (30).

Epidermal growth factor (EGF) receptor. Endocannabinoids decrease the expression of EGF receptors (31) and significantly inhibit the EGF-induced proliferation, migration and invasion of non-small cell lung cancer cell lines (32). The EGF cytoplasmic signaling pathways influence ER activity. The activation of EGF receptors leads to the MAPK-mediated phosphorylation 


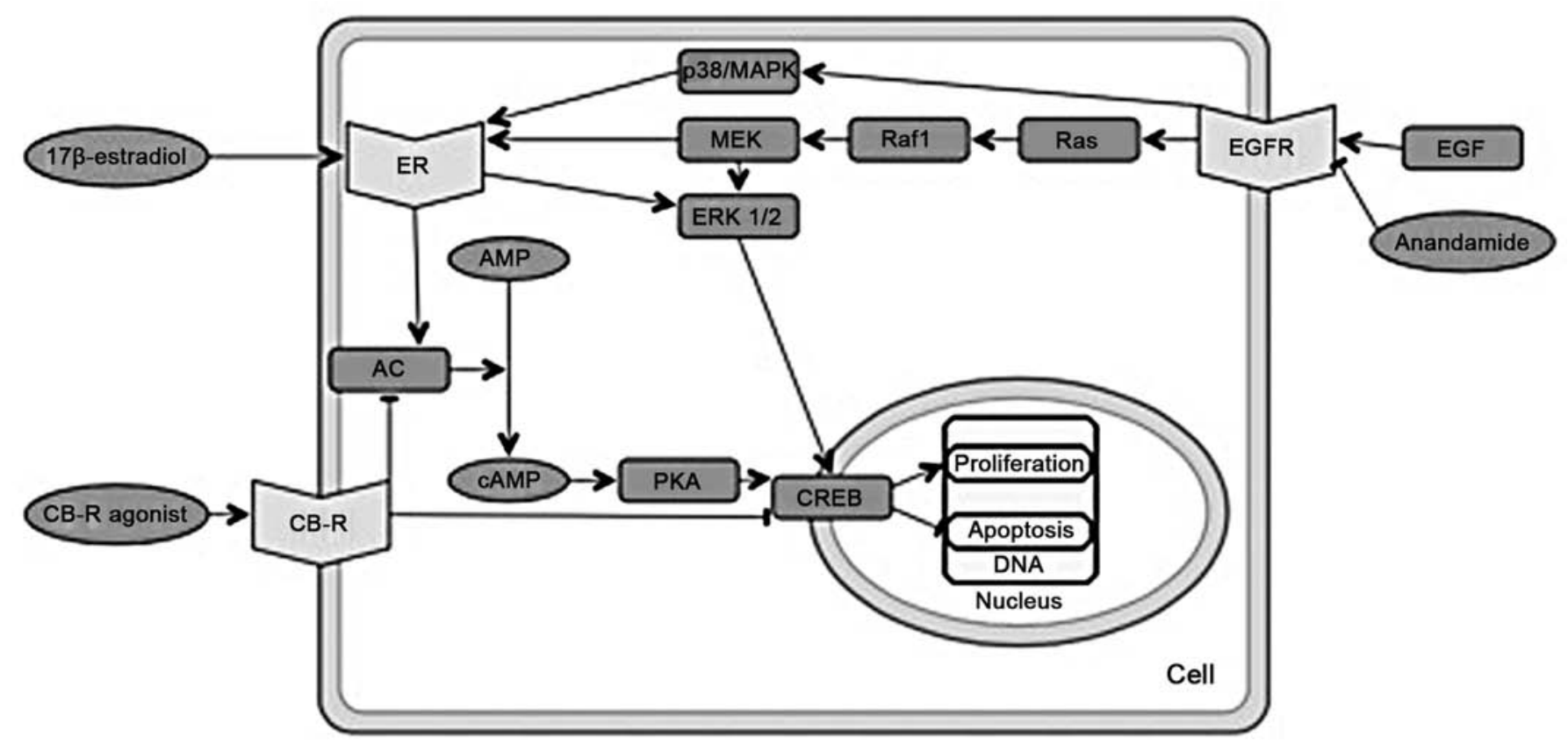

Figure 1. Overlapping molecular pathways of cannabinoids and estrogens. Part I. ER, estrogen receptor; CB-R, cannabinoid receptor; AC, adenylate cyclase; (c)AMP, (cyclic) adenosine monophosphate; PKA, protein kinase A; CREB, cAMP response element binding protein; CRE, cAMP response elements; EFG, epidermal growth factor; EGFR, epidermal growth factor receptor; Ras, rats sarcoma protein; Raf1, proto-oncogene serine/threonine-protein kinase; MEK, mitogen-activated protein kinase kinase; ERK1/2, extracellular-signal-regulated kinases 1/2; p38/MAPK, p38 mitogen-activated protein kinase.

of ER $\alpha$; in addition, EGF receptors activate p38/MAPKs that activate $\mathrm{ER} \alpha / \beta$ (33) (Fig. 1).

Cyclic adenosine monophosphate (cAMP) response element binding protein (CREB). After binding to ERs, estrogens can promote the activation of activating transcription factor (ATF)-2/ CREB to induce the expression of cyclin D1 and can promote the activation of ATF-1/CREB to induce the expression of B-cell lymphoma 2 protein (Bcl-2). Cyclin D1 and Bcl-2 are important for their proliferative and anti-apoptotic effects (34). The transcriptional activity of CREB can be induced by $17 \beta$-estradiol through the MAPK pathway, independently from the PKA pathway (35). Yet again, cannabinoids appear to have an opposite effect. It has been shown that cannabinoid agonists inhibit cAMP response elements (CRE) (36), the binding deoxyribonucleic acid (DNA) sequences for CREB (Fig. 1).

Prolactin. Endocannabinoids inhibit the mitogenic action of prolactin (37), which is among its others functions also an important inducer of carcinogenesis in breast cancer. Both estrogens and endocannabinoids regulate the expression of prolactin receptors $(37,38)$.

Vascular endothelial growth factor (VEGF). Cannabinoids cause a reduction in VEGF expression and inhibit angiogenesis through $\mathrm{CB} 1$ receptors. In mouse thyroid carcinoma, the reported anticancer effects of the CB1 receptor agonist, Met-Fanandamide, may be due to the inhibition of angiogenesis, as a consequence of VEGF signal blocking, the overexpression of cyclin-dependent kinase inhibitor 1 (p21) (39) and interference with VEGF receptor type 2 activation (40). By binding to EREs, $17 \beta$-estradiol directly regulates $V E G F$ gene transcription in endometrial cells and in Ishikawa adenocarcinoma cells. This mechanism may also be important in the estrogenic regulation of VEGF production and angiogenesis in estrogen target tissues, i.e., breast, bone, heart and skin $(41,42)$.

Proto-oncogene serine/threonine-protein kinase (Raf). Cannabinoids signal apoptosis via a pathway involving CB receptors. This pathway is sustained by ceramide accumulation and extracellular signal-regulated Raf kinase activation (43). The Raf kinase is activated by ER through non-genomic mechanisms. It has been demonstrated that in Chinese hamster ovary cells, serine 522 in the ligand binding domain of ER $\alpha$ interacts with caveolin-1. Caveolin-1 is a structural protein in caveolae that binds Raf, proto-oncogene tyrosineprotein kinase $(\mathrm{Src})$, growth factor receptor-bound protein 7 , rat sarcoma protein (Ras), mitogen-activated protein kinase kinase (MEK), EGF receptor and ER $\alpha$ at the plasma membrane, forming a 'signalsome' for the rapid activation of intracellular signaling (44, and refs therein). The protein Raf is important in the activation of MAPK and other kinases that are activated by estrogens (35).

$M A P K$. The MAPK pathway is generally important in gene expression, cell proliferation and apoptosis (45). Moreover, the activation of ER $\alpha$ or ER $\beta$ differentially affects proliferation and apoptosis. The $17 \beta$-estradiol-ER $\alpha$ complex activates multiple signaling pathways, including p38/MAPK, extracellular-signal-regulated kinase (ERK)/MAPK and phosphatidylinositol-4,5-bisphosphate 3-kinase (PI3K)/protein kinase B (Akt) which are involved in cell cycle progression and apoptotic cascade prevention. The $17 \beta$-estradiol-ER $\beta$ complex activates only the p38/MAPK pathway, which in turn leads to cell apoptosis (46). The ER-17 $\beta$-estradiol complex combined with the insulin-like growth factor-1 (IGF-1) receptor is also 


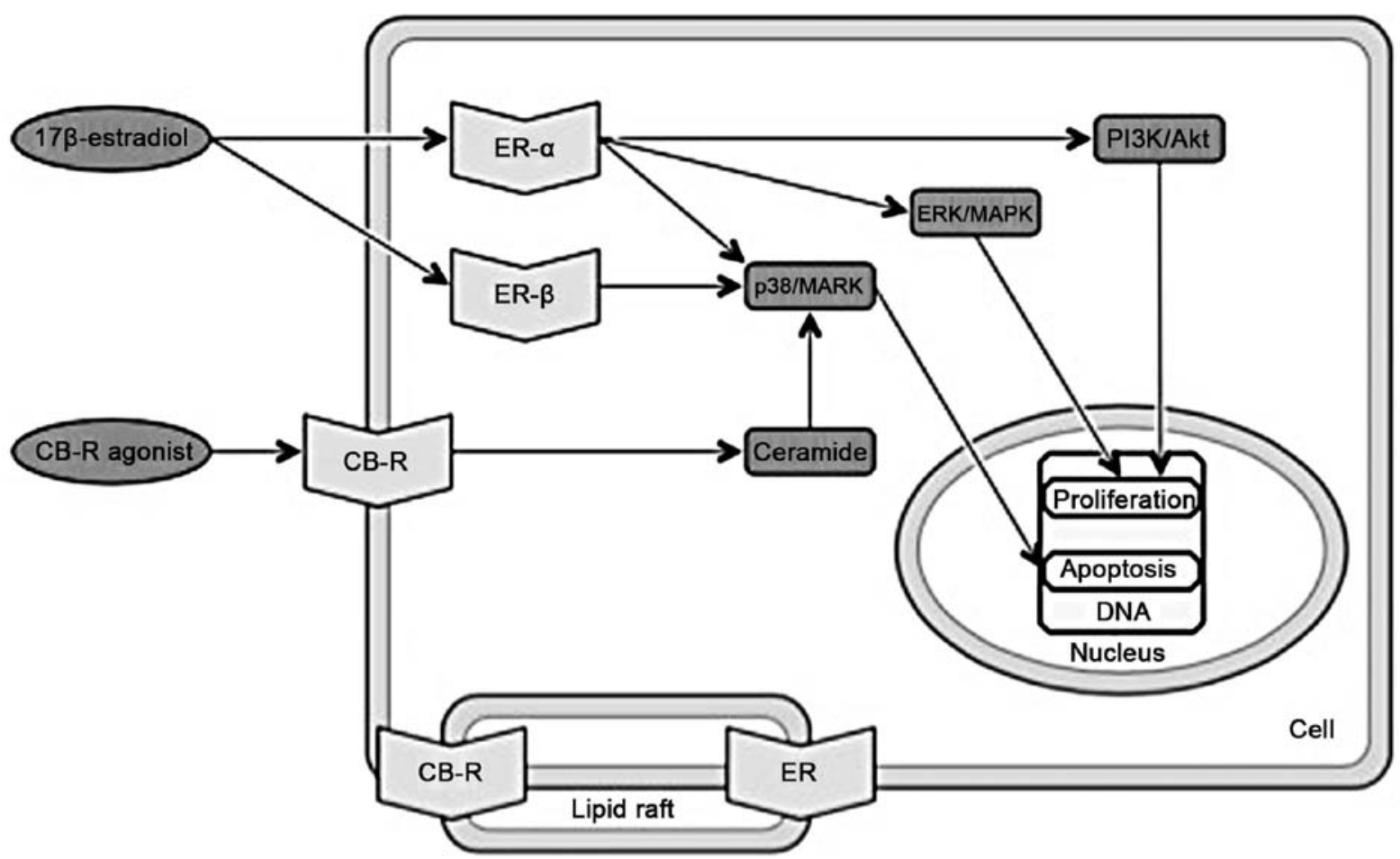

Figure 2. Overlapping molecular pathways of cannabinoids and estrogens. Part II. ER, estrogen receptor; CB-R, cannabinoid receptor; p38/MAPK, p38 mitogen-activated protein kinase; ERK, extracellular-signal-regulated kinase; MAPK, mitogen-activated protein kinase; PI3K, phosphatidylinositol-4,5-bisphosphate 3-kinase; Akt, serine-threonine specific protein kinase. CB-R can crosstalk with other receptors within lipid rafts including ERs (50).

a MAPK signaling pathway activator (47). Many apoptotic effects are also linked to $\mathrm{CB}$ receptors and the activation of MAPK pathways (48); e.g., ceramide synthesis is induced by cannabinoids and leads to the activation of the p38/MAPK pathway (49) (Fig. 2).

PI3K. Cannabinoids cause the downregulation of PI3K-Akt and ERK1/2 kinase signaling, which in turn inhibits proliferation and induces apoptosis (51). By contrast, 17 $\beta$-estradiol activates PI3K-mediated signaling, which causes rapid endothelial nitric-oxide synthesis (52) and promotes cell cycle progression (Fig. 3), also involving increased cyclin D1 expression (53).

C-Jun N-terminal kinase. C-Jun N-terminal kinase may be a potential target of ceramide action in the induction of apoptosis in a number of cell types (43). Estrogens also influence c-Jun N-terminal kinase. Estrogen receptors can associate with promoters/enhancers of the transcription factors ATF-2 and c-Jun. The activator protein-1 (AP-1) complex, consisting also of c-Jun, plays an important role in cell proliferation (34). Estrogen receptors enhance the transcription of genes that contain AP-1 (54). The activation of ER $\alpha$ activates AP-1-dependent transcription, whereas the activation of ER $\beta$ inhibits AP-1-dependent transcription (55). Cannabinoid agonists inhibit AP-1-mediated transcriptional activities, the latter being induced in several types of tumors (34) (Fig. 3).

ERK1/2. Current evidence indicates that a small population of $\operatorname{ER} \alpha$ and $\operatorname{ER} \beta$ localized at the plasma membrane exists within caveolar lipid rafts. It is at the plasma membrane that
$17 \beta$-estradiol-ER associates with the scaffolding protein, caveolin-1, and a variety of signal transduction cascades activations occur, including ERK and other enzymes [phospholipase C (PLC), protein kinase C (PKC), PI3K, nitric oxide synthase] (35). In bones, ER $\alpha$ is present in the caveolae of boneforming osteoblasts. The ER $\alpha$ transmits survival signals through the activation of the Src/adapter protein Shc/ERK pathway and prolongs the lifespan of osteoblasts (56). Cannabinoids activate ERK1/2 kinases, leading to G1 cell cycle arrest (57) (Fig. 3). The activation of either $\mathrm{CB} 1$ or $\mathrm{CB} 2$ receptors in colon cancer cells induces the Raf-MEK-ERK pathway to promote apoptosis and triggers the synthesis of ceramide (58).

Other molecular interactions. There is evidence to indicate that certain enzymes involved in the synthesis or degradation of endocannabinoids are also regulated by estrogens. Estrogens and progesterone downregulate uterine enzyme $\mathrm{N}$-acyl phosphatidylethanolamine phospholipase D (NAPE-PLD) expression via their nuclear receptors (59). Protein NAPE-PLD is an important enzyme in the synthesis of anandamide (60). Two endocannabinoids, anandamide and 2-AG, are oxidized by cyclooxygenase-2 (COX-2) (61). The $17 \beta$-estradiol exhibits a tendency to increase COX-2 expression and prostaglandin E2 synthesis in primary human uterine microvascular endothelial cells (62). As mentioned above, FAAH activity is inhibited by $17 \beta$-estradiol, which probably leads to higher concentrations of endocannabinoids after rising plasma estrogen levels (19). Accordingly, a homeostatic association between cannabinoids and estrogens can be proposed; increased levels of estrogens result in higher concentrations of endocannabinoids, which 


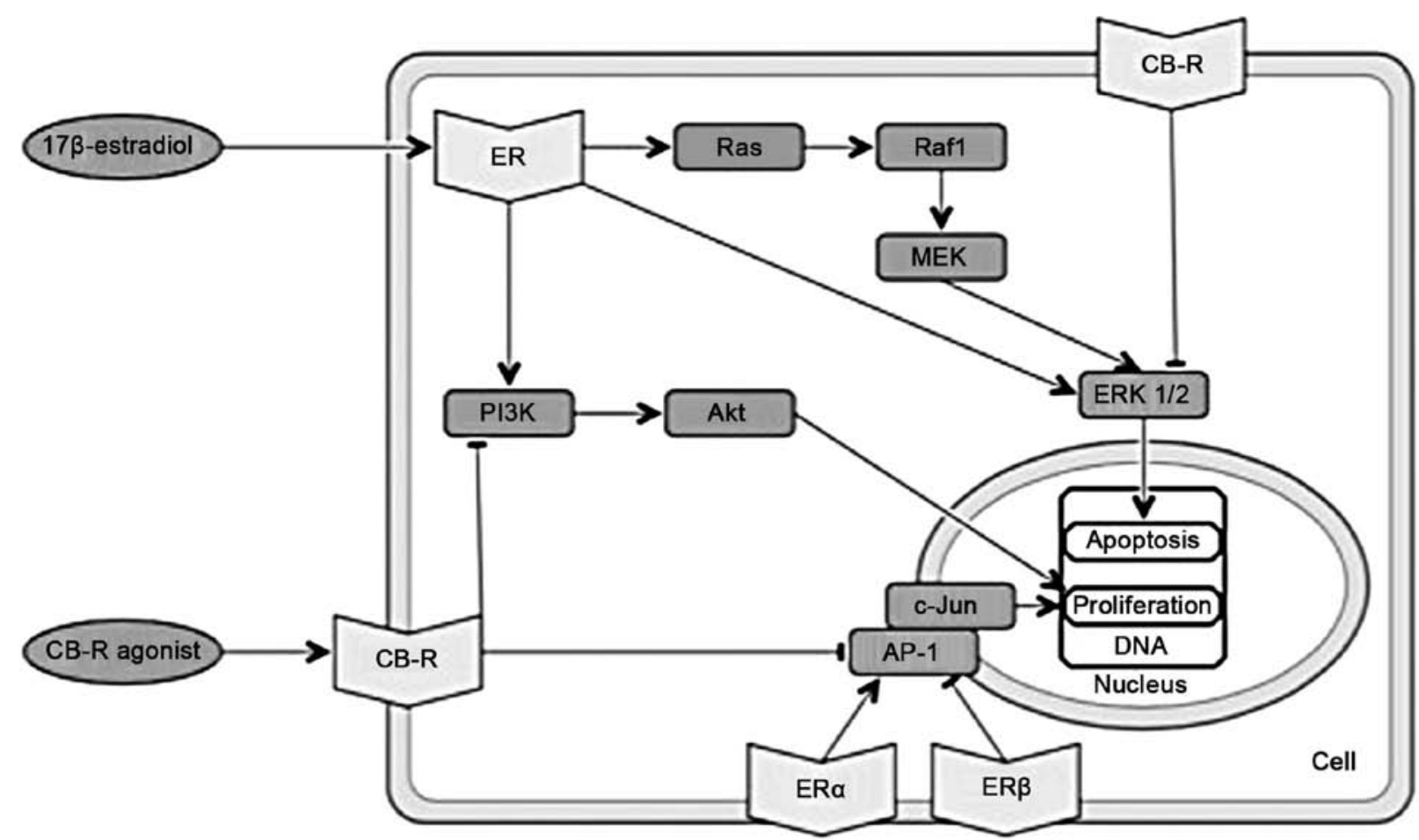

Figure 3. Overlapping molecular pathways of cannabinoids and estrogens. Part III. ER: estrogen receptor; CB-R, cannabinoid receptor; PI3K, phosphatidylinositol4,5-bisphosphate 3-kinase; Akt, serine-threonine specific protein kinase; AP-1, activator protein 1; c-Jun, protein encoded by the JUN gene; Ras, rats sarcoma protein; Raf1, proto-oncogene serine/threonine-protein kinase; MEK, mitogen-activated protein kinase kinase; ERK1/2, extracellular-signal-regulated kinases 1/2.

in turn inhibits the hypothalamic-pituitary-gonadal axis and leads to a decrease in estrogen levels (21). It also appears that endocannabinoids are released as a response to estrogen action and that they act via several molecular pathways, generally contradicting the effects of estrogens.

\section{Cannabinoids and estrogens and in common diseases}

Cannabinoids and estrogens in breast cancer. There is strong epidemiological, biological and clinical data that connects sex hormones, particularly estrogens, to breast cancer. The ER $\alpha$ is most directly implicated in the pathophysiology of the disease and its presence in tumor tissue is one of the most important disease prognostic factors. The role of other sex hormone receptors in the pathophysiology of breast cancer, i.e., ER $\beta$ and androgen receptors (ARs), has been less clearly investigated (63).

A recent study suggested that tamoxifen can act as a CB1 and $\mathrm{CB} 2$ inverse agonist, thus producing cytotoxicity via an ER-independent mechanism of action (25).

It has been shown that the activation of $\mathrm{CB} 2$ receptor by THC reduces the progression of the cell cycle and promotes the apoptosis of human breast cancer cells (64). Cannabidiol and most potently its analogue, 01663 , induce breast cancer cell death through apoptosis and autophagy in vitro (65), and they inhibit breast cancer cell proliferation and invasion in vivo (66); other synthetic cannabinoid receptor agonists also inhibit tumor growth and breast cancer metastasis (67). On the other hand, a previous study found that THC stimulates breast cancer growth and metastasis in vivo by the suppression of the body's antitumor immune response (68).
Cannabinoids and estrogens in endometrial cancer. Endometrial cancer is the most common gynecological malignancy. Prolonged unopposed estrogen exposure is associated with the majority of type I endometrial cancers. Estrogen replacement therapy, prescribed to control menopausal symptoms, increases the risk of developing endometrial cancer by 2-20-fold (69). Endometrial cancers are thought to arise from estrogen exposure, not balanced by the differentiating effects of progesterone (70). Currently, estrogen antagonists and progesterone analogues are used in endometrial cancer treatment (70).

A previous study demonstrated that anandamide may be a possible risk factor in endometrial cancer. Anandamide was shown to decrease both $\mathrm{CB} 1$ and $\mathrm{CB} 2$ receptor transcript levels in endometrial cancer tissues. In addition, plasma anandamide concentrations were significantly higher in patients with endometrial cancer than in the control group. This suggests that increased tissue and plasma anandamide concentrations may be in some way be linked to the pathophysiology of endometrial cancer (71).

In another study, the immunohistochemical analysis of endometrial biopsies revealed that $\mathrm{CB} 2$ receptors were selectively expressed in cancer cells, with a very weak expression in healthy cells in the same biopsies. Mass spectrometry analysis of endometrial carcinoma lipid extracts also revealed a significant increase in 2-AG levels in comparison with samples obtained from healthy subjects. No significant increase in the levels of anandamide was detected. The elevation of 2-AG is possibly due to the decrease in the expression of monoacylglycerol (MAGL), an important enzyme necessary for 2-AG breakdown (72). 


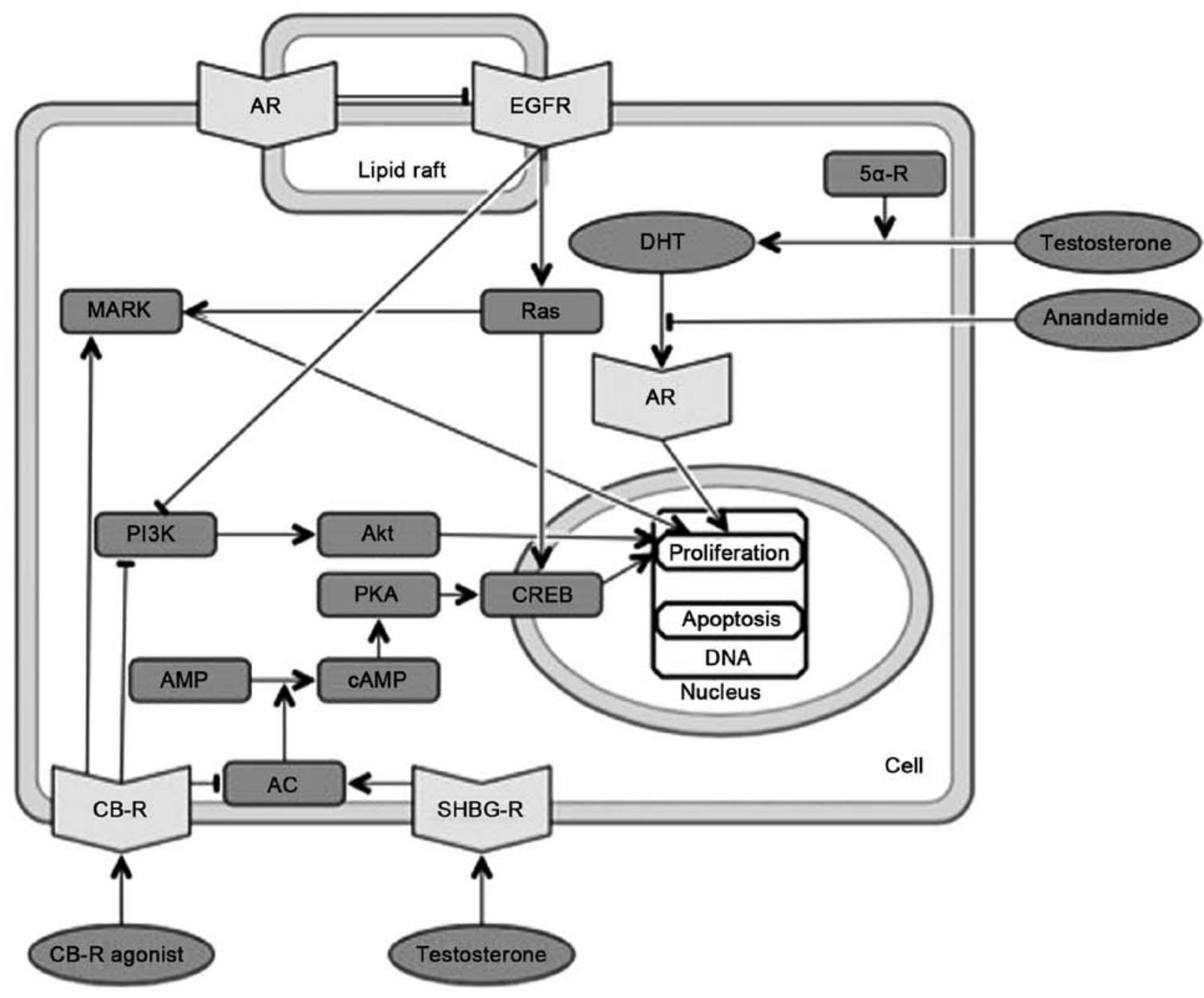

Figure 4. Overlapping molecular pathways of cannabinoids and androgens. CB-R, cannabinoid receptor; AR, androgen receptor; AC, adenylat cyclase; DHT, dihydrotestosterone; SHBG-R, sex hormone-binding globulin receptor; (c)AMP, (cyclic) adenosine monophosphate; PKA, protein kinase A; CREB, cAMP response element-biding protein; PI3K, phosphatidylinositol-4,5-bisphosphate 3-kinase; EGFR, epidermal growth factor receptor; Ras, rats sarcoma protein; MAPK, mitogen-activated protein kinase.

Cannabinoids and estrogens in osteoporosis. The bone remodeling process is influenced by many factors, including estrogens and endocannabinoids. Imbalances in bone remodeling mechanisms cause one of the most common degenerative diseases in developed countries, osteoporosis (73).

Osteoblasts and osteoclasts are influenced by estrogens at both the cellular and molecular level. Estrogens increase collagen I and osteoprotegerin expression $(74,75)$, there is evidence to suggests that estrogens have inhibitory effects on osteoblast apoptosis (76).

Cannabinoids also appear to modulate bone structure. Compared to $\mathrm{CB} 1$ receptors, $\mathrm{CB} 2$ receptors have been reported to have a significantly higher expression in osteoblasts, osteoclasts and osteocytes (77). Selective CB2 receptor agonists/ antagonists may therefore successfully regulate bone remodeling. Importantly, selective CB2 receptor ligands are not generally psychoactive, making them more suitable for potential clinical use (78).

There is evidence of estrogen and cannabinoid interactions in bone cells. Exposure to $17 \beta$-estradiol has been shown to lead to the increased expression of CB2 receptors in osteoclasts (21).
In our recent study on primary human osteoblasts, we reported a possible synergistic interaction between $17 \beta$-estradiol and a selective CB2 antagonist/inverse agonist (79).

Cannabinoids and estrogens in atherosclerosis. The pathophysiology underlying atherosclerosis is a combination of endothelial cell dysfunction and vascular inflammation, accompanied by a build-up of lipids, cholesterol and calcium within the tunica intima. In combination, these can result in plaque formation, thrombosis and cardiovascular insufficiency (80).

An increase in cardiovascular incidents in post-menopausal women suggests that estrogens play an essential protective role against cardiovascular disease. Menopause creates unhealthy changes in plasma lipoprotein levels that can be reversed by post-menopausal estrogen replacement therapy (81). Studies have demonstrated that estrogens are important for normal cell proliferation in blood vessels. When physiological angiogenesis is lacking or insufficient, a setting is created for various cardiovascular diseases (82). Estrogens regulate lipid and cholesterol levels and may provide protection by increasing plasma highdensity lipoprotein levels (83). Furthermore, estrogens may 
modulate inflammatory responses within vascular cells, may cause stem cell death and may also be involved in the development of hypertrophy (84).

The high expression of $\mathrm{CB} 1$ and $\mathrm{CB} 2$ receptors in atherosclerotic plaques indicates an important role of the endocannabinoid system in atherosclerosis (80). A higher expression of $\mathrm{CB} 1$ receptors is also associated with cardiovascular risk factors, such as obesity and dyslipidemia and CB1 agonists have been shown to increase the amount of reactive oxygen species, and thus to induce the apoptosis of endothelial cells in coronary arteries $(85,86)$. In an animal model of atherosclerosis, CB1 antagonists have proven useful; they reduce the accumulation of oxygenated low-density lipoproteins in macrophages, reduce inflammatory reactions in small blood vessels, decrease the proliferation of smooth muscle cells in vessel walls and, consequently, delay disease progression (80). The CB2 receptors have also been proven to play a significant role in the pathogenesis of atherosclerosis. In a previous study, the progression of atherosclerotic plaques in a mouse model was shown to be attenuated by the administration of THC. This effect was nullified by the subsequent administration of a selective CB2 antagonist (87). On the other hand, CB2 agonists reduce the accumulation of lipids in human foam cells (88). Cannabinoids also lower the expression of CD36 receptor, which promotes the release of pro-inflammatory cytokines and increases its own expression (89).

\section{Androgens}

The principle steroidal androgen testosterone and its more potent metabolite, 5-dihydrotestosterone (DHT), synthetized by enzyme $5 \alpha$-reductase, mediate their biological effects by binding to the AR. AR functions as a ligand-inducible transcription factor (90). In addition, evidence suggests that androgens can exert non-genomic effects. Non-genomic activity typically involves the rapid induction of conventional second messenger signal transduction cascades. The non-genomic effects of androgens can be mediated by at least three androgen-binding proteins, the classical intracellular AR, the transmembrane AR and the transmembrane sex hormone-binding globulin (SHBG) receptor (91). The non-genomic effects for transmembrane receptors are converted via a G-protein coupled processes, whereas binding to intracellular ARs may lead to an activation of several cytosolic pathways. Other androgen hormones that effect ARs are androstanediol, androstenedione, dehydroepiandrosterone and androsterone (91).

\section{Cannabinoids and androgens}

Studies have provided conflicting results as to whether chronic or acute marijuana use reduces the levels of circulating testosterone in humans. The influence of cannabinoids on androgens appears to be more consistent in animal models $(92,93)$. The exposure to THC in vitro has been shown to cause a decrease in testosterone production by mouse testes (94), and the chronic administration of THC to male mice has been shown to cause a reversible regression in Leyding cell tissues and the elimination of spermatogenesis (95). THC has been shown to exert anti-androgenic effects in adult castrated rats (96). The chronic administration of high doses of THC to male dogs has been shown to cause testicular degeneration (97). The acute administration is effective in reducing serum testosterone levels (14).

\section{Overlapping molecular pathways of cannabinoids and androgens}

Androgens are involved in molecular pathways that are also affected by endocannabinoids (Fig. 4). Non-genomic androgen activity involves the rapid induction of conventional second messenger signal transduction cascades, including increases in free intracellular calcium and the activation of PKA, PKC and MAPK, leading to diverse cellular effects, including smooth muscle relaxation, neuromuscular signal transmission and neuronal plasticity (90). In prostate cancer cells, MAPK activation by AR/Src/protein MNAR pathway has been shown to be both androgen-dependent and -independent $(98,99)$.

Testosterone may exert its effects through the SHBG receptor complex. The SHBG binds gonadal steroids and acts as a docking station for free testosterone or other steroids to act on cells without entering them. The activation of the SHBG receptor results in the activation of $\mathrm{AC}$, the rapid generation of cAMP and the activation of PKA. These secondary messenger actions affect the transcriptional activity of classic, intracellular receptors for steroid hormones (100).

Androgens can interact with certain growth factors and ARs are activated by growth factors, such as IGF, EGF, interleukin-6 and others (101). In PC3-AR cells it was observed that a pool of classical ARs is located within lipid rafts and a population of EGF receptors is located within cholesterolrich membrane microdomains (102). The interaction between ARs and EGF receptors on the plasma membrane decreases the EGF-mediated phosphorylation and PI3K/Akt downstream signaling of EGF receptor (103).

There is little direct evidence of interactions between cannabinoids and the androgen system. However, it has been demonstrated that marihuana, THC and cannabinol inhibit dihydrotestosterone binding to ARs (104).

\section{Cannabinoids and androgens in common diseases}

Cannabinoids and androgens in prostate cancer. The induction of prostatic cancer by androgens (specifically by testosterone replacement therapy) is still a controversial issue (105), but there is little doubt that the activation of AR by testosterone and dihydroxytestosterone contributes significantly to the progression of metastatic prostate cancer (106). Cannabinoids, on the other hand, have some protective functions. Synthetic cannabinoid quinoines have anti-proliferative effects in vitro and prostate antitumor activity in vivo (107). Another study found that cannabidiol inhibited prostate carcinoma growth in vitro and in vivo via the stimulation of intrinsic pathways of apoptosis. The pro-apoptotic effects of cannabidiol were due to transient receptor potential cation channel subfamily $\mathrm{M}$ member 8 (TRPM8) antagonism, the downregulation of AR, p53 activation and the elevation of reactive oxygen species (108).

\section{Conclusions}

Sex hormones play a very important evolutionary role in reassuring the propagation of species. They may be protective in 
some instances (i.e., the protective properties of estrogens against cardiovascular diseases); however, they often have toxic effects due to their cancer-inducing properties and their involvement in autoimmune diseases. The cancer-inducing properties of estrogens have been particularly well documented in breast and endometrial cancer. It has been shown that there is a positive correlation of peak plasma anandamide with $17 \beta$-estradiol and gonadotropin levels at ovulation (19). This may indicate the body's protective reaction against rising levels of sex hormones. The same principles may apply to cannabinoids and prostate cancer. We propose that the endocannabinoid system may be a body-wide protective system against the harmful effects of sex hormones. The two systems are probably antagonistic, thus maintaining homeostasis. Common molecular pathways, in which both cannabinoids and sex hormones affect cell proliferation and apoptosis, require further investigation in order to clarify their molecular interactions.

\section{References}

1. Han S, Thatte J, Buzard DJ and Jones RM: Therapeutic utility of cannabinoid receptor type $2(\mathrm{CB}(2))$ selective agonists. J Med Chem 56: 8224-8256, 2013

2. Ryberg E, Larsson N, Sjögren S, Hjorth S, Hermansson NO, Leonova J, Elebring T, Nilsson K, Drmota T and Greasley PJ: The orphan receptor GPR55 is a novel cannabinoid receptor. Br J Pharmacol 152: 1092-1101, 2007.

3. McHugh D, Hu SS, Rimmerman N, Juknat A, Vogel Z, Walker JM and Bradshaw HB: $\mathrm{N}$-arachidonoyl glycine, an abundant endogenous lipid, potently drives directed cellular migration through GPR18, the putative abnormal cannabidiol receptor. BMC Neurosci 11: 44, 2010.

4. Brown AJ: Novel cannabinoid receptors. Br J Pharmacol 152: 567-575, 2007.

5. Starowicz K, Nigam S and Di Marzo V: Biochemistry and pharmacology of endovanilloids. Pharmacol Ther 114: 13-33, 2007

6. Kushner PJ, Agard DA, Greene GL, Scanlan TS, Shiau AK, Uht RM and Webb P: Estrogen receptor pathways to AP-1. J Steroid Biochem Mol Biol 74: 311-317, 2000.

7. Hammes SR and Levin ER: Minireview: Recent advances in extranuclear steroid receptor actions. Endocrinology 152 4489-4495, 2011.

8. Coleman KM and Smith CL: Intracellular signaling pathways: Nongenomic actions of estrogens and ligand-independent activation of estrogen receptors. Front Biosci 6: D1379-D1391, 2001.

9. Prossnitz ER, Arterburn JB and Sklar LA: GPR30: A G proteincoupled receptor for estrogen. Mol Cell Endocrinol 265-266: 138-142, 2007.

10. Paterni I, Granchi C, Katzenellenbogen JA and Minutolo F: Estrogen receptors alpha $(\mathrm{ER} \alpha)$ and beta $(\mathrm{ER} \beta)$ : Subtype-selective ligands and clinical potential. Steroids 90: 13-29, 2014.

11. John E: Hall: Guyton and Hall Textbook of Medical Physiology. 12th edition. Saunders, pp991-992, 2010.

12. Tyrey L: delta-9-Tetrahydrocannabinol suppression of episodic luteinizing hormone secretion in the ovariectomized rat. Endocrinology 102: 1808-1814, 1978.

13. Tyrey L: delta 9-Tetrahydrocannabinol: A potent inhibitor of episodic luteinizing hormone secretion. J Pharmacol Exp Ther 213: 306-308, 1980

14. Kumar MS and Chen CL: Effect of an acute dose of delta 9-THC on hypothalamic luteinizing hormone releasing hormone and met-enkephalin content and serum levels of testosterone and corticosterone in rats. Subst Alcohol Actions Misuse 4: 37-43, 1983.

15. Scorticati C, Fernández-Solari J, De Laurentiis A, Mohn C, Prestifilippo JP, Lasaga M, Seilicovich A, Billi S, Franchi A, McCann SM, et al: The inhibitory effect of anandamide on luteinizing hormone-releasing hormone secretion is reversed by estrogen. Proc Natl Acad Sci USA 101: 11891-11896, 2004.

16. Gammon CM, Freeman GM Jr, Xie W, Petersen SL and Wetsel WC: Regulation of gonadotropin-releasing hormone secretion by cannabinoids. Endocrinology 146: 4491-4499, 2005 .
17. Cravatt BF, Giang DK, Mayfield SP, Boger DL, Lerner RA and Gilula NB: Molecular characterization of an enzyme that degrades neuromodulatory fatty-acid amides. Nature 384: 83-87, 1996.

18. MacCarrone M, De Felici M, Bari M, Klinger F, Siracusa G and Finazzi-Agrò A: Downregulation of anandamide hydrolase in mouse uterus by sex hormones. Eur J Biochem 267: 2991-2997, 2000.

19. El-Talatini MR, Taylor AH and Konje JC: The relationship between plasma levels of the endocannabinoid, anandamide, sex steroids, and gonadotrophins during the menstrual cycle. Fertil Steril 93: 1989-1996, 2010.

20. Gorzalka BB and Dang SS: Minireview: Endocannabinoids and gonadal hormones: bidirectional interactions in physiology and behavior. Endocrinology 153: 1016-1024, 2012.

21. Rossi F, Bellini G, Luongo L, Mancusi S, Torella M, Tortora C, Manzo I, Guida F, Nobili B, de Novellis V and Maione S: The $17-\beta$-oestradiol inhibits osteoclast activity by increasing the cannabinoid CB2 receptor expression. Pharmacol Res 68: 7-15, 2013.

22. Notarnicola M, Messa C, Orlando A, Bifulco M, Laezza C, Gazzerro P and Caruso MG: Estrogenic induction of cannabinoid CB1 receptor in human colon cancer cell lines. Scand J Gastroenterol 43: 66-72, 2008.

23. Riebe CJ, Hill MN, Lee TT, Hillard CJ and Gorzalka BB: Estrogenic regulation of limbic cannabinoid receptor binding. Psychoneuroendocrinology 35: 1265-1269, 2010.

24. Kumar P and Song ZH: CB2 cannabinoid receptor is a novel target for third-generation selective estrogen receptor modulators bazedoxifene and lasofoxifene. Biochem Biophys Res Commun 443: 144-149, 2014.

25. Prather PL, FrancisDevaraj F, Dates CR, Greer AK, Bratton SM, Ford BM, Franks LN and Radominska-Pandya A: CB1 and CB2 receptors are novel molecular targets for Tamoxifen and 4OH-Tamoxifen. Biochem Biophys Res Commun 441: 339-343, 2013.

26. Melck D, Rueda D, Galve-Roperh I, De Petrocellis L, Guzmán M and Di Marzo V: Involvement of the cAMP/protein kinase A pathway and of mitogen-activated protein kinase in the antiproliferative effects of anandamide in human breast cancer cells. FEBS Lett 463: 235-240, 1999.

27. Gu Q and Moss RL: 17 beta-Estradiol potentiates kainate-induced currents via activation of the cAMP cascade. J Neurosci 16: 3620-3629, 1996.

28. Picotto G, Massheimer V and Boland R: Acute stimulation of intestinal cell calcium influx induced by 17 beta-estradiol via the cAMP messenger system. Mol Cell Endocrinol 119: 129-134, 1996.

29. Watters JJ and Dorsa DM: Transcriptional effects of estrogen on neuronal neurotensin gene expression involve cAMP/protein kinase A-dependent signaling mechanisms. J Neurosci 18: 6672-6680, 1998.

30. Szego CM and Davis JS: Adenosine 3',5'-monophosphate in rat uterus: Acute elevation by estrogen. Proc Natl Acad Sci USA 58: 1711-1718, 1967.

31. Mimeault M, Pommery N, Wattez N, Bailly C and Hénichart JP: Anti-fn of epidermal growth factor receptor downregulation and ceramide production. Prostate 56: 1-12, 2003

32. Preet A, Qamri Z, Nasser MW, Prasad A, Shilo K, Zou X, Groopman JE and Ganju RK: Cannabinoid receptors, CB1 and CB2, as novel targets for inhibition of non-small cell lung cancer growth and metastasis. Cancer Prev Res (Phila) 4: 65-75, 2011.

33. Driggers PH and Segars JH: Estrogen action and cytoplasmic signaling pathways. Part II: The role of growth factors and phosphorylation in estrogen signaling. Trends Endocrinol Metab 13: 422-427, 2002.

34. O'Lone R, Frith MC, Karlsson EK and Hansen U: Genomic targets of nuclear estrogen receptors. Mol Endocrinol 18: 1859-1875, 2004.

35. Marino M, Galluzzo P and Ascenzi P: Estrogen signaling multiple pathways to impact gene transcription. Curr Genomics 7: 497-508, 2006

36. Bosier B, Hermans E and Lambert D: Differential modulation of AP-1- and CRE-driven transcription by cannabinoid agonists emphasizes functional selectivity at the $\mathrm{CB} 1$ receptor. $\mathrm{Br} \mathrm{J}$ Pharmacol 155: 24-33, 2008.

37. Melck D, De Petrocellis L, Orlando P, Bisogno T, Laezza C, Bifulco M and Di Marzo V: Suppression of nerve growth factor Trk receptors and prolactin receptors by endocannabinoids leads to inhibition of human breast and prostate cancer cell proliferation. Endocrinology 141: 118-126, 2000. 
38. Watters JJ, Chun TY, Kim YN, Bertics PJ and Gorski J: Estrogen modulation of prolactin gene expression requires an intact mitogen-activated protein kinase signal transduction pathway in cultured rat pituitary cells. Mol Endocrinol 14: 1872-1881, 2000.

39. Portella G, Laezza C, Laccetti P, De Petrocellis L, Di Marzo V and Bifulco M: Inhibitory effects of cannabinoid CB1 receptor stimulation on tumor growth and metastatic spreading: Actions on signals involved in angiogenesis and metastasis. FASEB J 17: 1771-1773, 2003.

40. Blázquez C, González-Feria L, Alvarez L, Haro A, Casanova ML and Guzmán M: Cannabinoids inhibit the vascular endothelial growth factor pathway in gliomas. Cancer Res 64: 5617-5623, 2004

41. Mueller MD, Vigne JL, Minchenko A, Lebovic DI, Leitman DC and Taylor RN: Regulation of vascular endothelial growth factor (VEGF) gene transcription by estrogen receptors alpha and beta. Proc Natl Acad Sci USA 97: 10972-10977, 2000.

42. Stoner M, Wang F, Wormke M, Nguyen T, Samudio I, Vyhlidal C, Marme D, Finkenzeller G and Safe S: Inhibition of vascular endothelial growth factor expression in HEC1A endometrial cancer cells through interactions of estrogen receptor alpha and Sp3 proteins. J Biol Chem 275: 22769-22779, 2000.

43. Galve-Roperh I, Sánchez C, Cortés ML, Gómez del Pulgar T, Izquierdo M and Guzmán M: Anti-tumoral action of cannabinoids: Involvement of sustained ceramide accumulation and extracellular signal-regulated kinase activation. Nat Med 6: 313-319, 2000.

44. Klinge CM, Blankenship KA, Risinger KE, Bhatnagar S, Noisin EL, Sumanasekera WK, Zhao L, Brey DM and Keynton RS: Resveratrol and estradiol rapidly activate MAPK signaling through estrogen receptors alpha and beta in endothelial cells. J Biol Chem 280: 7460-7468, 2005.

45. Pearson G, Robinson F, Beers Gibson T, Xu BE, Karandikar M, Berman K and Cobb MH: Mitogen-activated protein (MAP) kinase pathways: Regulation and physiological functions. Endocr Rev 22: 153-183, 2001.

46. Acconcia F, Totta P, Ogawa S, Cardillo I, Inoue S, Leone S, Trentalance A, Muramatsu M and Marino M: Survival versus apoptotic 17beta-estradiol effect: Role of ER alpha and ER beta activated non-genomic signaling. J Cell Physiol 203: 193-201, 2005.

47. Kahlert S, Nuedling S, van Eickels M, Vetter H, Meyer R and Grohe C: Estrogen receptor alpha rapidly activates the IGF-1 receptor pathway. J Biol Chem 275: 18447-18453, 2000.

48. Pertwee RG, Howlett AC, Abood ME, Alexander SP, Di Marzo V, Elphick MR, Greasley PJ, Hansen HS, Kunos G, Mackie K, et al: International Union of Basic and Clinical Pharmacology. LXXIX. Cannabinoid receptors and their ligands: Beyond CB1 and CB2. Pharmacol Rev 62: 588-631, 2010.

49. Ramer R, Weinzierl U, Schwind B, Brune K and Hinz B: Ceramide is involved in $\mathrm{r}(+)$-methanandamide-induced cyclooxygenase-2 expression in human neuroglioma cells. Mol Pharmacol 64: 1189-1198, 2003

50. Pisanti S, Picardi P, D'Alessandro A, Laezza C and Bifulco $M$ The endocannabinoid signaling system in cancer. Trends Pharmacol Sci 34: 273-282, 2013.

51. Ellert-Miklaszewska A, Kaminska B and Konarska L: Cannabinoids downregulate PI3K/Akt and Erk signalling pathways and activate proapoptotic function of Bad protein. Cell Signal 17: 25-37, 2005.

52. Haynes MP, Li L, Sinha D, Russell KS, Hisamoto K, Baron R, Collinge M, Sessa WC and Bender JR: Src kinase mediates phosphatidylinositol 3-kinase/Akt-dependent rapid endothelial nitric-oxide synthase activation by estrogen. J Biol Chem 278 : 2118-2123, 2003

53. Marino M, Acconcia F and Trentalance A: Biphasic estradiolinduced AKT phosphorylation is modulated by PTEN via MAP kinase in HepG2 cells. Mol Biol Cell 14: 2583-2591, 2003.

54. Gaub MP, Bellard M, Scheuer I, Chambon P and Sassone-Corsi P: Activation of the ovalbumin gene by the estrogen receptor involves the fos-jun complex. Cell 63: 1267-1276, 1990.

55. Paech K, Webb P, Kuiper GG, Nilsson S, Gustafsson J, Kushner PJ and Scanlan TS: Differential ligand activation of estrogen receptors ERalpha and ERbeta at AP1 sites. Science 277: 1508-1510, 1997.

56. Kousteni S, Han L, Chen JR, Almeida M, Plotkin LI, Bellido T and Manolagas SC: Kinase-mediated regulation of common transcription factors accounts for the bone-protective effects of sex steroids. J Clin Invest 111: 1651-1664, 2003.

57. Sarfaraz S, Afaq F, Adhami VM, Malik A and Mukhtar H: Cannabinoid receptor agonist-induced apoptosis of human prostate cancer cells LNCaP proceeds through sustained activation of ERK1/2 leading to G1 cell cycle arrest. J Biol Chem 281: 39480-39491, 2006
58. Cianchi F, Papucci L, Schiavone N, Lulli M, Magnelli L, Vinci MC, Messerini L, Manera C, Ronconi E, Romagnani P, et al: Cannabinoid receptor activation induces apoptosis through tumor necrosis factor alpha-mediated ceramide de novo synthesis in colon cancer cells. Clin Cancer Res 14: 7691-7700, 2008.

59. Guo Y, Wang H, Okamoto Y, Ueda N, Kingsley PJ, Marnett LJ, Schmid HH, Das SK and Dey SK: N-acylphosphatidylethanolamine-hydrolyzing phospholipase $\mathrm{D}$ is an important determinant of uterine anandamide levels during implantation. J Biol Chem 280: 23429-23432, 2005.

60. Tsuboi K, Okamoto Y, Ikematsu N, Inoue M, Shimizu Y, Uyama T, Wang J, Deutsch DG, Burns MP, Ulloa NM, et al: Enzymatic formation of $\mathrm{N}$-acylethanolamines from $\mathrm{N}$-acylethanolamine plasmalogen through $\mathrm{N}$-acylphosphatidylethanolaminehydrolyzing phospholipase D-dependent and -independent pathways. Biochim Biophys Acta 1811: 565-577, 2011.

61. Urquhart P, Nicolaou A and Woodward DF: Endocannabinoids and their oxygenation by cyclo-oxygenases, lipoxygenases and other oxygenases. Biochim Biophys Acta 1851: 366-376, 2015.

62. Tamura M, Deb S, Sebastian S, Okamura K and Bulun SE Estrogen up-regulates cyclooxygenase-2 via estrogen receptor in human uterine microvascular endothelial cells. Fertil Steril 81: 1351-1356, 2004

63. Higa GM and Fell RG: Sex hormone receptor repertoire in breast cancer. Int J Breast Cancer 2013: 284036, 2013.

64. Caffarel MM, Sarrió D, Palacios J, Guzmán M and Sánchez C: Delta9-tetrahydrocannabinol inhibits cell cycle progression in human breast cancer cells through $\mathrm{Cdc} 2$ regulation. Cancer Res 66: 6615-6621, 2006

65. Shrivastava A, Kuzontkoski PM, Groopman JE and Prasad A Cannabidiol induces programmed cell death in breast cancer cells by coordinating the cross-talk between apoptosis and autophagy. Mol Cancer Ther 10: 1161-1172, 2011.

66. Murase R, Kawamura R, Singer E, Pakdel A, Sarma P, Judkins J, Elwakeel E, Dayal S, Martinez-Martinez E, Amere M, et al: Targeting multiple cannabinoid anti-tumour pathways with a resorcinol derivative leads to inhibition of advanced stages of breast cancer. Br J Pharmacol 171: 4464-4477, 2014

67. Qamri Z, Preet A, Nasser MW, Bass CE, Leone G, Barsky SH and Ganju RK: Synthetic cannabinoid receptor agonists inhibit tumor growth and metastasis of breast cancer. Mol Cancer Ther 8: 3117-3129, 2009.

68. McKallip RJ,Nagarkatti MandNagarkattiPS: Delta-9-tetrahydrocannabinol enhances breast cancer growth and metastasis by suppression of the antitumor immune response. J Immunol 174: 3281-3289, 2005

69. SGO Clinical Practice Endometrial Cancer Working Group, Burke WM, Orr J, Leitao M, Salom E, Gehrig P, Olawaiye AB, Brewer M, Boruta D, Villella J, Herzog T and Abu Shahin F; Society of Gynecologic Oncology Clinical Practice Committee: Endometrial cancer: A review and current management strategies: part I. Gynecol Oncol 134: 385-392, 2014.

70. Tangen IL, Werner HM, Berg A, Halle MK, Kusonmano K, Trovik J, Hoivik EA, Mills GB, Krakstad C and Salvesen HB: Loss of progesterone receptor links to high proliferation and increases from primary to metastatic endometrial cancer lesions. Eur J Cancer 50: 3003-3010, 2014.

71. Ayakannu A, Taylor AH, Marczylo TH, Willets JM, Brown L, Davies Q, Moss E and Konje JC: Association of cannabinoid receptor expression with anandamide concentrations in endometrial cancer. Lancet Volume 383: S23, 2014.

72. Guida M, Ligresti A, De Filippis D, D'Amico A, Petrosino S, Cipriano M, Bifulco G, Simonetti S, Orlando P, Insabato L, et al: The levels of the endocannabinoid receptor CB2 and its ligand 2-arachidonoylglycerol are elevated in endometrial carcinoma. Endocrinology 151: 921-928, 2010.

73. Raisz LG: Pathogenesis of osteoporosis: Concepts, conflicts, and prospects. J Clin Invest 115: 3318-3325, 2005.

74. Centrella M and McCarthy TL: Estrogen receptor dependent gene expression by osteoblasts - direct, indirect, circumspect, and speculative effects. Steroids 77: 174-184, 2012.

75. Bilezikian JP, Raisz LG and Martin TJ: Principles of Bone Biology. 3rd edition. Elsevier, Amsterdam, pp855-885, 2008.

76. Bradford PG, Gerace KV, Roland RL and Chrzan BG: Estrogen regulation of apoptosis in osteoblasts. Physiol Behav 99: 181-185, 2010.

77. Ofek O, Karsak M, Leclerc N, Fogel M, Frenkel B, Wright K, Tam J, Attar-Namdar M, Kram V, Shohami E, et al: Peripheral cannabinoid receptor, CB2, regulates bone mass. Proc Natl Acad Sci USA 103: 696-701, 2006. 
78. Hanus L, Breuer A, Tchilibon S, Shiloah S, Goldenberg D, Horowitz M, Pertwee RG, Ross RA, Mechoulam R and Fride E: HU-308: A specific agonist for $\mathrm{CB}(2)$, a peripheral cannabinoid receptor. Proc Natl Acad Sci USA 96: 14228-14233, 1999.

79. Hojnik M, Dobovišek L, Knez Ž and Ferk P: A synergistic interaction of $17-\beta$-estradiol with specific cannabinoid receptor type 2 antagonist/inverse agonist on proliferation activity in primary human osteoblasts. Biomed Rep 3: 554-558, 2015.

80. Steffens S, Veillard NR, Arnaud C, Pelli G, Burger F, Staub C, Karsak M, Zimmer A, Frossard JL and Mach F: Low dose oral cannabinoid therapy reduces progression of atherosclerosis in mice. Nature 434: 782-786, 2005.

81. Paganini-Hill A,Dworsky R and Krauss RM:Hormone replacement therapy, hormone levels, and lipoprotein cholesterol concentrations in elderly women. Am J Obstet Gynecol 174: 897-902, 1996.

82. Boosani CS and Sudhakar YA: Proteolytically derived endogenous angioinhibitors originating from the extracellular matrix. Pharmaceuticals (Basel) 4: 1551-1577, 2011.

83. Deroo BJ and Korach KS: Estrogen receptors and human disease. J Clin Invest 116: 561-570, 2006

84. Murphy E: Estrogen signaling and cardiovascular disease. Circ Res 109: 687-696, 2011

85. Dol-Gleizes F, Paumelle R, Visentin V, Marés AM, Desitter P Hennuyer N, Gilde A, Staels B, Schaeffer P and Bono F: Rimonabant, a selective cannabinoid CB1 receptor antagonist, inhibits atherosclerosis in LDL receptor-deficient mice. Arterioscler Thromb Vasc Biol 29: 12-18, 2009.

86. Pacher P: Cannabinoid CB1 receptor antagonists for atherosclerosis and cardiometabolic disorders: New hopes, old concerns? Arterioscler Thromb Vasc Biol 29: 7-9, 2009.

87. Mach F, Montecucco F and Steffens S: Cannabinoid receptors in acute and chronic complications of atherosclerosis. $\mathrm{Br} \mathrm{J}$ Pharmacol 153: 290-298, 2008.

88. Chiurchiù V, Lanuti M, Catanzaro G, Fezza F, Rapino $C$ and Maccarrone M: Detailed characterization of the endocannabinoid system in human macrophages and foam cells, and anti-inflammatory role of type- 2 cannabinoid receptor. Atherosclerosis 233 55-63, 2014.

89. Collot-Teixeira S, Martin J, McDermott-Roe C, Poston R and McGregor JL: CD36 and macrophages in atherosclerosis. Cardiovasc Res 75: 468-477, 2007.

90. Heinlein CA and Chang C: The roles of androgen receptors and androgen-binding proteins in nongenomic androgen actions. Mol Endocrinol 16: 2181-2187, 2002

91. Michels G and Hoppe UC: Rapid actions of androgens. Front Neuroendocrinol 29: 182-198, 2008.

92. Cohen S: The 94-day cannabis study. Ann NY Acad Sci 282: 211-220, 1976

93. Block RI, Farinpour R and Schlechte JA: Effects of chronic marijuana use on testosterone, luteinizing hormone, follicle stimulating hormone, prolactin and cortisol in men and women. Drug Alcohol Depend 28: 121-128, 1991.

94. Dalterio S, Bartke A and Burstein S: Cannabinoids inhibit testosterone secretion by mouse testes in vitro. Science 196: 1472-1473, 1977.
95. Dixit VP, Sharma VN and Lohiya NK: The effect of chronically administered cannabis extract on the testicular function of mice. Eur J Pharmacol 26: 111-114, 1974.

96. Ghosh SP, Chatterjee TK and Ghosh JJ: Antiandrogenic effect of delta-9-tetrahydrocannabinol in adult castrated rats. J Reprod Fertil 62: 513-517, 1981

97. Dixit VP, Gupta CL and Agrawal M: Testicular degeneration and necrosis induced by chronic administration of cannabis extract in dogs. Endokrinologie 69: 299-305, 1977.

98. Migliaccio A, Castoria G, Di Domenico M, de Falco A, Bilancio A, Lombardi M, Barone MV, Ametrano D, Zannini MS, Abbondanza C and Auricchio F: Steroid-induced androgen receptor-oestradiol receptor beta-Src complex triggers prostate cancer cell proliferation. EMBO J 19: 5406-5417, 2000.

99. Unni E, Sun S, Nan B, McPhaul MJ, Cheskis B, Mancini MA and Marcelli M: Changes in androgen receptor nongenotropic signaling correlate with transition of $\mathrm{LNCaP}$ cells to androgen independence. Cancer Res 64: 7156-7168, 2004.

100. Li J and Al-Azzawi F: Mechanism of androgen receptor action. Maturitas 63: 142-148, 2009.

101. Taichman RS, Loberg RD, Mehra R and Pienta KJ: The evolving biology and treatment of prostate cancer. J Clin Invest 117: 2351-2361, 2007.

102. Bonaccorsi L, Nosi D, Quercioli F, Formigli L, Zecchi S, Maggi M, Forti G and Baldi E: Prostate cancer: A model of integration of genomic and non-genomic effects of the androgen receptor in cell lines model. Steroids 73: 1030-1037, 2008.

103. Bonaccorsi L, Nosi D, Muratori M, Formigli L, Forti G and Baldi E: Altered endocytosis of epidermal growth factor receptor in androgen receptor positive prostate cancer cell lines. J Mol Endocrinol 38: 51-66, 2007.

104. Purohit V, Ahluwahlia BS and Vigersky RA: Marihuana inhibits dihydrotestosterone binding to the androgen receptor. Endocrinology 107: 848-850, 1980

105. Grech A, Breck J and Heidelbaugh J: Adverse effects of testosterone replacement therapy: An update on the evidence and controversy. Ther Adv Drug Saf 5: 190-200, 2014.

106. Ahmed A, Ali S and Sarkar FH: Advances in androgen receptor targeted therapy for prostate cancer. J Cell Physiol 229: 271-276, 2014.

107. Morales P, Vara D, Goméz-Cañas M,Zúñiga MC, Olea-Azar C, Goya P, Fernández-Ruiz J, Díaz-Laviada I and Jagerovic N: Synthetic cannabinoid quinones: Preparation, in vitro antiproliferative effects and in vivo prostate antitumor activity. Eur J Med Chem 70: 111-119, 2013.

108. De Petrocellis L, Ligresti A, Schiano Moriello A, Iappelli M, Verde R, Stott CG, Cristino L, Orlando P and Di Marzo V: Non-THC cannabinoids inhibit prostate carcinoma growth in vitro and in vivo: Pro-apoptotic effects and underlying mechanisms. Br J Pharmacol 168: 79-102, 2013. 